Gut, 1972, 13, 887-893

\title{
Plasma gastrin and acid secretion in man following stimulation by food, meat extract, and insulin
}

\author{
J. H. WYllie, P. B. Boulos, M. R. LEWIN, B. H. STAGG, AND C. G. ClARK \\ From the Department of Surgery, University College Hospital Medical School, London, England
}

SUMMARY A radioimmunoassay for gastrin was set up and its sensitivity and specificity were studied. The assay was then used to investigate the plasma gastrin responses in man to a normal meal and to stimulation by insulin hypoglycaemia or by instilling meat extract into the stomach. The results showed that insulin and meat extract produced very similar plasma gastrin responses which were certainly not less than those produced by feeding. However, the acid secretory response to insulin was greater than that to meat extract. This indicated that the tests acted in different ways and both may be useful in the assessment of gastric secretion.

Radioimmunoassays have recently made it possible to measure the concentration of gastrin in human plasma (Hansky and Cain, 1969; Byrnes, Young, Chisholm, and Lazarus, 1970; McGuigan and Trudeau, 1970; Yalow and Berson, 1970). It has been shown that the plasma gastrin rises in response to such stimuli as the ingestion of food and insulin hypoglycaemia. However, little is known about any quantitative relationships which may exist between plasma gastrin levels and gastric acid secretion. There is no direct method of measuring gastric secretion in man following a normal meal, and the response to insulin hypoglycaemia may involve both direct vagal stimulation of acid secretion and indirect stimulation mediated by gastrin. It would, therefore, be useful if a test could be devised in which antral gastrin release was powerfully stimulated and in which plasma gastrin levels and gastric acid secretion could be simultaneously measured. The 'antral function test' of Giles and Clark (1966) appears to meet these requirements. In this test, a meat extract (Oxo) is instilled into the stomach via a nasogastric tube, left there for 15 minutes, and removed by aspiration. Afterwards there is usually a marked stimulation of gastric acid secretion which can be followed by continuous aspiration of gastric juice. In experiments reported in this paper we have used such a test (hereafter called the 'Oxo test') to relate gastric acid secretion to plasma gastrin levels. The results have been compared with those obtained in the same subjects either by feeding a standard meal or by provoking insulin hypoglycaemia.

Received for publication 6 September 1972.

\section{Methods}

RADIOIMMUNOASSAY OF GASTRIN

Antisera to gastrin were raised in four cross-bred New Zealand white rabbits by immunization with synthetic human gastrin I (SHG), residues 2-17, conjugated to crystalline bovine plasma albumin. The conjugation reaction was carried out using water-soluble 1-ethyl-3-(3-dimethylaminopropyl) carbodiimide hydrochloride ${ }^{1}$ and yielded a product in which an average of 10 molecules of SHG were linked per molecule of bovine plasma albumin. Each rabbit received the equivalent of $2 \mathrm{mg}$ of $\mathrm{SHG}$, the antigen being administered by injection into the footpads as an emulsion in Freund's complete adjuvant. Such immunizing injections were given three times at three-monthly intervals, after which one rabbit produced an antiserum of suitable titre and avidity. This antiserum was used in all the gastrin assays.

Synthetic human gastrin I was labelled with ${ }^{125}$ I by a modification of the chloramine-T method of Hunter and Greenwood (1962). To $2 \mathrm{mCi}$ of $\mathrm{Na}^{125} \mathrm{I}$ (IMS 3; Radiochemical Centre, Amersham, UK) were added $2 \mu \mathrm{g}$ of SHG and $50 \mu \mathrm{g}$ of chloramine-T, followed after one min by $250 \mu \mathrm{g}$ of sodium metabisulphite. All the reactants were dissolved in $0.5 \mathrm{M}$ potassium phosphate buffer, $p \mathrm{H} \mathrm{7.4}$. The reaction mixture was then applied to a $1 \times 15 \mathrm{~cm}$ column of Sephadex G-10 ( $5 \mathrm{~g}$ ), equilibrated and eluted with $0 \cdot 1 \mathrm{M}$ potassium phosphate- $0 \cdot 15 \mathrm{M}$ $\mathrm{NaCl}$ buffer, $p \mathrm{H} \mathrm{7 \cdot 4}$. The ${ }^{125} \mathrm{I}-\mathrm{SHG}$ was eluted in the

${ }^{1}$ Goodfriend, Levine, and Fasman (1964). 
void volume of the column and had a specific activity in the range $300-500 \mu \mathrm{Ci}$ per $\mu \mathrm{g}$ gastrin.

The radioimmunoassay was routinely carried out in a total volume of $0.5 \mathrm{ml}$, in which $0.1 \mathrm{ml}$ of antiserum (final dilution 1/5000) was incubated with $0.1 \mathrm{ml}$ of ${ }^{125} \mathrm{I}-\mathrm{SHG}$ (5 pg giving $\left.2500-3500 \mathrm{cpm}\right)$. To this was added $0.1 \mathrm{ml}$ of either standard solutions containing known amounts of SHG in the range $5-100 \mathrm{pg}$ or $0.1 \mathrm{ml}$ of plasma. These reagents were prepared in $0 \cdot 1 \mathrm{M}$ potassium phosphate- $0 \cdot 15 \mathrm{M}$ $\mathrm{NaCl}$ buffer, $p \mathrm{H} 7 \cdot 4$, containing $1 \%$ human serum albumin. The reaction mixtures were incubated for $48 \mathrm{hr}$ at $4^{\circ} \mathrm{C}$. The total radioactivity was counted in an automatic scintillation well counter (Packard Autogamma Spectrometer, series 5000) with the $\gamma$-ray setting at $12-90 \mathrm{KeV}$. Then the antibodybound and the free labelled SHG were separated by adsorption of the latter to charcoal coated with dextran T-70 (Pharmacia) using the method of Herbert, Lau, Gottlieb, and Bleicher (1965).

Adsorbed radioactivity was then counted and the antibody-bound radioactivity was given by the difference between the two counts. Samples and standards were always assayed in duplicate.

\section{GASTRIC SECRETION TESTS}

The subjects of these experiments were two normal volunteers and nine patients awaiting surgery for duodenal ulceration. All subjects gave informed consent for the investigations. To allow measurement of acid secretion the subjects starved overnight and then swallowed no. 14 French gauge nasogastric tubes which were positioned as recommended by Hassan and Hobsley (1970).

Gastric juice was collected in 15-minute samples by continuous suction at $4 \mathrm{~cm} \mathrm{Hg}$ pressure. After noting the volume, the acidity was titrated against $0 \cdot 1 \mathrm{~N} \mathrm{NaOH}$ to a phenolphthalein endpoint.

The peak acid output of all subjects was first measured by collecting the gastric juice every 15 min for one hour after the subcutaneous injection of $6 \mu \mathrm{g} / \mathrm{kg}$ of pentagastrin. The two samples with the highest successive acid outputs were used to calculate the peak acid output which was expressed as mequiv/hour.

In the other tests gastric secretion was stimulated either by insulin hypoglycaemia, meat extract, or a meal. Blood samples were taken for blood sugar measurements just before intravenous injection of insulin $(0 \cdot 15 \mathrm{IU} / \mathrm{kg}$ body weight) and again 30 minutes later. The blood sugar fell from a mean of $70 \mathrm{mg} / 100 \mathrm{ml}$ (range 66 to 78 ) before the injection of insulin to a mean of $22 \mathrm{mg} / 100 \mathrm{ml}$ (range 17 to 27) following the injection of insulin. Gastric juice was collected in 15-minute samples for two hours. In tests with meat extract (Oxo), basal secretion was first measured for one hour. Meat extract was prepared by dissolving three cubes of Oxo in $100 \mathrm{ml}$ of water and adjusting the $p \mathrm{H}$ to 7.0 using $1 \mathrm{M}$ $\mathrm{NaHCO}_{3}$. This solution was instilled through the nasogastric tube into the stomach where it was left for 15 minutes. At the end of this period it was aspirated and collection of gastric juice was resumed for one hour.

Six subjects also ate a standard meal whose composition is shown in Table I; this allowed study of the plasma gastrin response to a completely physiological stimulus. No attempt was made to measure acid secretion in these tests.

\begin{tabular}{llll}
\hline & $\begin{array}{l}\text { Protein } \\
(\mathrm{g})\end{array}$ & $\begin{array}{l}\text { Fat } \\
(\mathrm{g})\end{array}$ & $\begin{array}{l}\text { Total } \\
\text { Calories }\end{array}$ \\
\hline 130 g (raw) grilled steak & $26 \cdot 8$ & $12 \cdot 3$ & 224 \\
$5 \mathrm{~g}$ butter & - & $4 \cdot 3$ & 39 \\
60 g mashed potato & $0 \cdot 9$ & $3 \cdot 0$ & 72 \\
60 g peas & $3 \cdot 0$ & - & 29 \\
40 g grilled skinned tomato & $0 \cdot 3$ & - & 6 \\
30 g vanilla ice-cream & $1 \cdot 2$ & $3 \cdot 4$ & 59 \\
60 g tinned peaches & - & - & 52 \\
& $32 \cdot 2$ & $23 \cdot 0$ & 481 \\
\hline
\end{tabular}

Table I Composition of the standard meal employed in tests to stimulate antral gastrin release

Blood samples $(10 \mathrm{ml})$ for plasma gastrin estimation were drawn from an indwelling intravenous cannula which was filled with $0 \cdot 15 \mathrm{M} \mathrm{NaCl}$ to prevent clotting between drawing samples. The first $2 \mathrm{ml}$ of blood withdrawn on each occasion was discarded to avoid dilution of samples with sodium chloride solution. The blood samples were placed in heparinized tubes, mixed, and centrifuged for three minutes at $3000 \mathrm{rpm}$. The plasma was at once separated and stored at $-20^{\circ} \mathrm{C}$ for up to one month until the gastrin assays were performed.

\section{Results}

THE GASTRIN ASSAY

Before studying plasma gastrin levels in man the following features of the gastrin assay were evaluated.

\section{Standard curve}

A typical standard curve for the radioimmunoassay is shown in Figure 1. The percentage of ${ }^{125} \mathrm{I}-\mathrm{SHG}$ bound by antibody was plotted against increasing amounts of unlabelled SHG in the range 5-100 pg (equivalent to $50-1000 \mathrm{pg}$ per $\mathrm{ml}$ of plasma). The percentage of ${ }^{125} \mathrm{I}$-SHG bound decreased from 38.2 in the absence of added unlabelled hormone to $6 \cdot 1$ with $100 \mathrm{pg}$ of synthetic human gastrin I. The most sensitive portion of the curve was the region from 5 


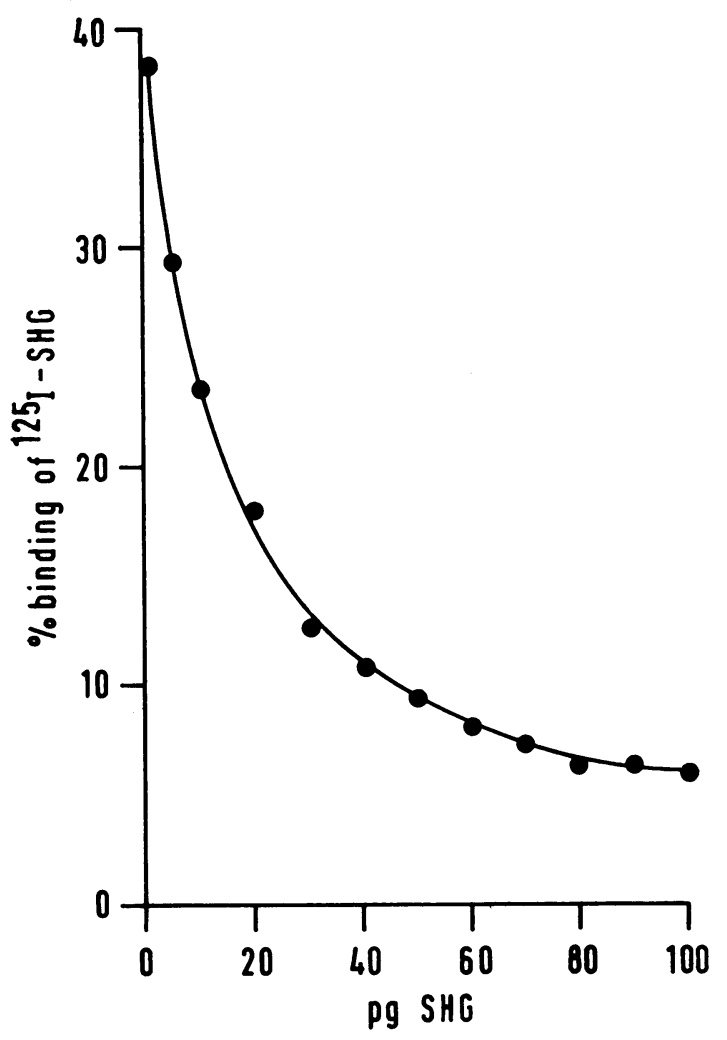

Fig. 1 Standard curve for the radioimmunoassay of gastrin.

to $40 \mathrm{pg}$ ( 50 to $400 \mathrm{pg}$ per $\mathrm{ml}$ of plasma). Successive assays gave very similar standard curves.

Identical curves were obtained when the standards were prepared in either buffer or in gastrin-free plasma prepared by treatment of normal fasting plasma with Amberlite CG-4B ion-exchange resin (Yalow and Berson, 1970). Statistical analysis of the results of this recovery experiment yielded a highly significant correlation coefficient $(r=0.99 ; P<0.001)$ indicating that the assay had a high degree of accuracy. Also, the dilution of plasma samples containing known concentrations of gastrin gave curves which could be superimposed upon the standard curve of the radioimmunoassay.

\section{Sensitivity}

The gradient of the initial slope of the standard curve (Fig. 1) indicated that less than $5 \mathrm{pg}$ of free gastrin would be measurable. However, since the plasma samples were routinely assayed at a dilution of $1: 5$, and since the lowest standard employed was equivalent to a gastrin concentration of $50 \mathrm{pg}$ per $\mathrm{ml}$, no interpolation was made between 0 and 50 pg per ml. Hence, the sensitivity of the assay can be stated to be $5 \mathrm{pg}$ absolute or $50 \mathrm{pg}$ per ml. Plasmas with gastrin concentrations less than $50 \mathrm{pg}$ per $\mathrm{ml}$ were expressed as such.

\section{Reproducibility}

Since tests on patients were performed over a period of nine months, it was important to know whether the gastrin assay yielded reproducible results over the whole of this period. This was tested by assaying three normal fasting plasma samples in 10 separate assays spread over the relevant period. The results (Table II) showed that the assay was highly reproducible, the within-assay and between-assay coefficients of variation being 6.8 and 6.2 respectively. These results also implied that human plasma gastrin was stable at $-20^{\circ} \mathrm{C}$ for up to nine months.

\begin{tabular}{|c|c|c|c|}
\hline \multirow[t]{2}{*}{ Assay } & \multicolumn{3}{|c|}{ Plasma Gastrin Level (pg/ml) } \\
\hline & Sample 1 & Sample 2 & Sample 3 \\
\hline 1 & $\begin{array}{r}95 \\
106\end{array}$ & $\begin{array}{l}67 \\
60\end{array}$ & $\begin{array}{r}110 \\
98\end{array}$ \\
\hline 2 & $\begin{array}{r}105 \\
90\end{array}$ & $\begin{array}{l}60 \\
65\end{array}$ & $\begin{array}{r}100 \\
92\end{array}$ \\
\hline 3 & $\begin{array}{l}90 \\
87\end{array}$ & $\begin{array}{l}75 \\
70\end{array}$ & $\begin{array}{l}88 \\
97\end{array}$ \\
\hline 4 & $\begin{array}{l}110 \\
103\end{array}$ & $\begin{array}{l}60 \\
68\end{array}$ & $\begin{array}{l}105 \\
115\end{array}$ \\
\hline 5 & $\begin{array}{l}97 \\
85\end{array}$ & $\begin{array}{l}55 \\
65\end{array}$ & $\begin{array}{l}113 \\
105\end{array}$ \\
\hline 6 & $\begin{array}{l}90 \\
95\end{array}$ & $\begin{array}{l}62 \\
60\end{array}$ & $\begin{array}{l}95 \\
87\end{array}$ \\
\hline 7 & $\begin{array}{l}100 \\
105\end{array}$ & $\begin{array}{l}62 \\
75\end{array}$ & $\begin{array}{l}107 \\
105\end{array}$ \\
\hline 8 & $\begin{array}{r}107 \\
95\end{array}$ & $\begin{array}{l}77 \\
62\end{array}$ & $\begin{array}{l}115 \\
112\end{array}$ \\
\hline 9 & $\begin{array}{r}98 \\
100\end{array}$ & $\begin{array}{l}58 \\
65\end{array}$ & $\begin{array}{l}85 \\
92\end{array}$ \\
\hline 10 & $\begin{array}{l}85 \\
95\end{array}$ & $\begin{array}{l}65 \\
68\end{array}$ & $\begin{array}{l}90 \\
92\end{array}$ \\
\hline
\end{tabular}

Table II Results and statistical analysis of gastrin assays of three fasting plasma samples each carried out in duplicate on 10 occasions

\begin{tabular}{lllll}
\hline & Variance & SD & $\begin{array}{l}\text { Coefficient } \\
\text { of Variation }\end{array}$ & $\begin{array}{l}95 \% \text { Con- } \\
\text { fidence } \\
\text { Interval }\end{array}$ \\
\hline $\begin{array}{l}\text { Within assay } \\
\text { Between }\end{array}$ & 35.80 & 5.98 & 6.85 & \pm 13.43 \\
assay & 28.97 & 5.35 & 6.16 & \pm 11.15 \\
\hline
\end{tabular}

Table IIa Statistical analysis

Specificity

Gastrin shares the same C-terminal tetrapeptide sequence with cholecystokinin (Mutt and Jorpes, 1968), caerulein (Anastasi, Erspamer, and Endean, 1967), and pentagastrin. The cross reactivities of these structurally related peptides were therefore studied, and the results are shown in Figure 2. None 


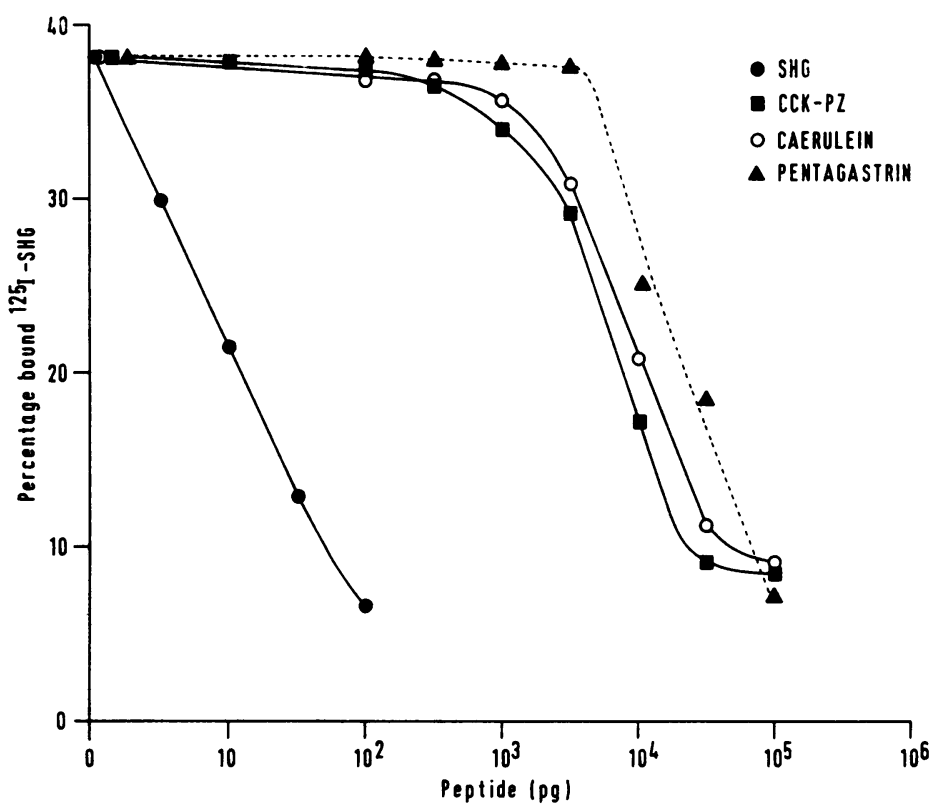

Fig. 2 Inhibition of binding of ${ }_{125}$ I-SHG to antiserum in the presence of different concentrations of SHG, cholecystokinin, caerulein, and pentagastrin. of the three related peptides showed any significant effect on the binding of ${ }^{125} \mathrm{I}$-SHG below $10^{3} \mathrm{pg}$. Of these peptides, only cholecystokinin might have been present in the plasma samples in our experiments.

Dilutions of Oxo were tested for ability to bind to antibody; no such activity was found up to a concentration of $62 \mathrm{mg} / \mathrm{ml}$. This concentration might be attained transiently in the plasma following the rapid ingestion of 30 cubes of Oxo. Since only three cubes were used, the possibility of interference can be discounted.

PLASMA GASTRIN LEVELS AND ACID SECRETION

Plasma gastrin levels in Oxo tests and after a standard meal

Six subjects, two normal and four with duodenal ulcers, were studied to compare the plasma gastrin levels after a standard meal and after Oxo. The tests were performed on different days. A substantial rise in plasma gastrin levels occurred in response to both stimuli in all subjects (Fig. 3). Food caused the mean plasma gastrin concentration to increase from 72 to $200 \mathrm{pg} / \mathrm{ml}$; Oxo caused an increase from 95 to 470 $\mathrm{pg} / \mathrm{ml}$.

Statistical testing to ascertain whether Oxo produced a greater rise in plasma gastrin than did the standard meal showed that results just failed to reach significance at the $5 \%$ level. The experiments revealed that the Oxo test produced gastrin levels which were at least as high as those following an ordinary meal. We therefore concluded that the Oxo test could be used to study both endogenous gastrin release and the relationship between plasma gastrin levels and acid secretion.

Plasma gastrin levels in Oxo tests and in insulin tests Seven patients underwent preoperative tests of gastric secretion using pentagastrin, Oxo, and insulin hypoglycaemia to stimulate secretion. Acid secretion was measured in all tests and plasma gastrin levels were measured in Oxo and insulin tests.

Table III shows the peak rate of acid secretion in these three types of test. In each case the peak rate in $\mathrm{m}$-equiv/hour was estimated from the rate of secretion observed in the two consecutive 15minute periods giving the highest values. It may be seen that the peak secretion rate after insulin averaged $84 \%$ of that after pentagastrin. In fact the results with pentagastrin and insulin did not differ significantly in a paired-sample $t$ test. This confirmed the established fact that insulin can stimulate acid secretion at nearly the maximal rate (Clark, Curnow, Murray, Stephens, and Wyllie, 1964; Hubel, 1966). Peak acid secretion in Oxo tests was significantly lower than that in either insulin or pentagastrin $(P<0.05, \quad P<0.01$ respectively). On average, the peak secretion after Oxo was $54 \%$ of that reached with pentagastrin. Thus, Oxo provided a weaker stimulus to acid secretion than either insulin or pentagastrin. 




Fig. 3 Comparison of the plasma gastrin response to a standard meal and to Oxo.

\begin{tabular}{|c|c|c|c|c|c|c|c|}
\hline \multirow[t]{2}{*}{ Patient } & \multirow[t]{2}{*}{ Sex } & \multirow[t]{2}{*}{$\begin{array}{c}\text { Age } \\
(y r)\end{array}$} & \multicolumn{3}{|c|}{ Peak Acid Output (m-equiv/hr) Stimulated by } & \multicolumn{2}{|c|}{$\begin{array}{l}\text { Peak Plasma Gastrin Level }(\mathrm{pg} / \mathrm{ml}) \text { Stimulated } \\
\text { by }\end{array}$} \\
\hline & & & Pentagastrin & Oxo & Insulin & Oxo & Insulin \\
\hline \multirow[t]{2}{*}{$\begin{array}{l}1 \\
2 \\
3 \\
4 \\
5 \\
6 \\
7\end{array}$} & $\begin{array}{l}\mathbf{M} \\
\mathbf{M} \\
\mathbf{M} \\
\mathbf{M} \\
\mathbf{M} \\
\mathbf{M} \\
\mathbf{F}\end{array}$ & $\begin{array}{l}57 \\
33 \\
39 \\
42 \\
47 \\
33 \\
\mathbf{4 8}\end{array}$ & $\begin{array}{l}40 \cdot 6 \\
45.2 \\
36.4 \\
30 \cdot 2 \\
51.0 \\
45.4 \\
57.8\end{array}$ & $\begin{array}{r}38.4 \\
21.2 \\
8.0 \\
14.2 \\
19.6 \\
21.4 \\
43.8\end{array}$ & $\begin{array}{l}26 \cdot 2 \\
32 \cdot 4 \\
30 \cdot 2 \\
38 \cdot 6 \\
43 \cdot 0 \\
48 \cdot 6 \\
38 \cdot 2\end{array}$ & $\begin{array}{l}340 \\
395 \\
307 \\
375 \\
345 \\
370 \\
465\end{array}$ & $\begin{array}{l}240 \\
397 \\
160 \\
312 \\
355 \\
445 \\
435\end{array}$ \\
\hline & $\begin{array}{l}\text { Mean } \\
\pm \text { SEM }\end{array}$ & $\begin{array}{r}43 \\
\pm 3\end{array}$ & $\begin{array}{r}43 \cdot 8 \\
\pm 3 \cdot 5\end{array}$ & $\begin{array}{r}23 \cdot 8 \\
\pm 4 \cdot 8\end{array}$ & $\begin{array}{r}36 \cdot 7 \\
\pm 2.9\end{array}$ & $\begin{array}{r}371 \\
\pm 19\end{array}$ & $\begin{array}{r}335 \\
\pm 40\end{array}$ \\
\hline
\end{tabular}

Table III Peak acid output stimulated by pentagastrin, Oxo, and insulin and peak plasma gastrin levels stimulated by $O x o$ and insulin in patients with duodenal ulceration

A comparison of the plasma gastrin responses in Oxo and insulin tests is shown in Figure 4. It can be seen that the plasma gastrin responses follow very similar patterns. The basal level in Oxo tests (mean $86 \mathrm{pg} / \mathrm{ml}$ ) was not significantly different from that in insulin tests (mean $113 \mathrm{pg} / \mathrm{ml}$ ); the peak levels reached were virtually identical. The response to insulin hypoglycaemia, unlike that to Oxo, showed a definite latency, but the time courses of the responses were otherwise quite similar.

The bottom half of Fig. 4 shows the mean acid secretion in the two types of test and confirms the 


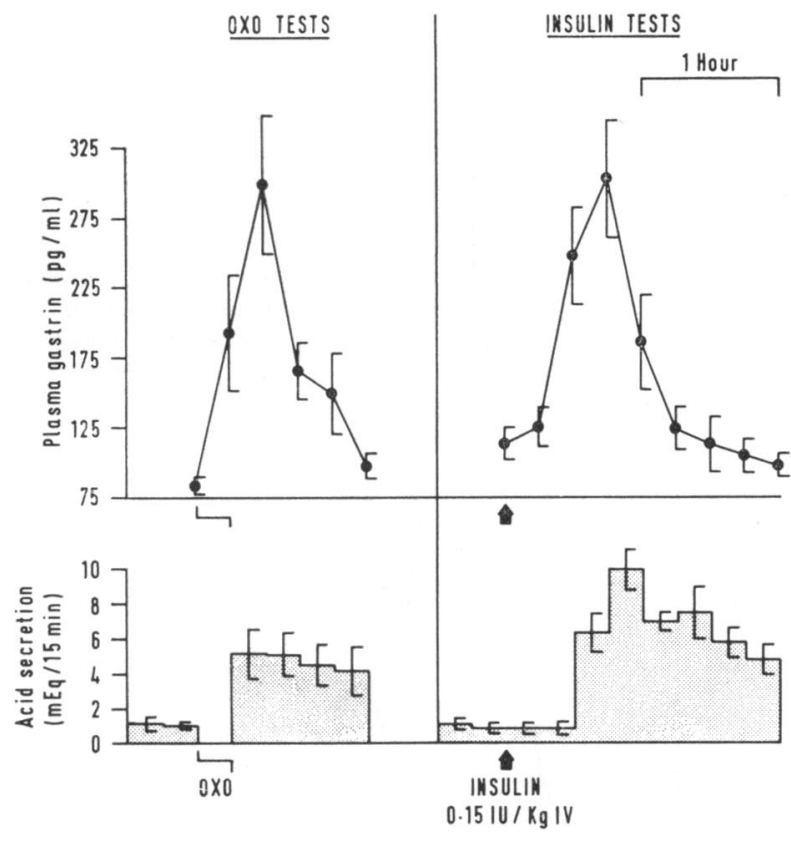

Fig. 4 Comparison of the plasma gastrin and acid secretory responses to $O x o$ and to insulin hypoglycaemia.

conclusion already reached that acid secretion was more strongly stimulated by insulin hypoglycaemia than by Oxo. Thus, the acid secretion differed significantly, although the plasma gastrin responses were indistinguishable.

\section{Discussion}

A radioimmunoassay is indispensable for measuring plasma gastrin levels. Bioassay methods are so insensitive that they can only detect grossly elevated levels such as occur in the Zollinger-Ellison syndrome, and they are too cumbersome to allow easy measurement of rapidly changing concentrations. The methods used to obtain suitable antisera were similar to those of McGuigan (1970) and the resulting assay was sufficiently sensitive to detect 5 pg of free gastrin. Since $0.1 \mathrm{ml}$ of plasma was routinely used in assays this allowed measurement of plasma gastrin levels in the range $50-1000 \mathrm{pg} / \mathrm{ml}$ without any dilution of plasma samples or modification of standard assay conditions. In only a few instances did samples have gastrin levels below 50 $\mathrm{pg} / \mathrm{ml}$ and there were no samples with levels as high as $1000 \mathrm{pg} / \mathrm{ml}$.

The reproducibility of the assay was good both for replicate estimations in a single assay and for estimations repeated in different assays. This allowed comparisons to be made between the results of tests performed months apart. Also, the antiserum appeared to be specific for gastrin in that it reacted only feebly with cholecystokinin and other gastrinlike peptides.

Release of cholecystokinin occurs following normal meals, and possibly also in Oxo tests. However, Young, Lazarus, Chisholm, and Atkinson (1969) have measured postprandial cholecystokinin levels and their results imply that endogenous cholecystokinin would not interfere in our assays for gastrin. It cannot be denied that other circulating peptides might react in the assay. It is known that our assay system can detect gastrin degradation products (Lewin, Hunziker, Stagg, and Wyllie, 1971) and it has also been found that some biologically active gastrin-like substances present in the plasma are not detected (Temperley and Stagg, 1971). This implies that the radioimmunoassay cannot measure absolute levels of biologically active gastrin in plasma samples. Nevertheless, we believe that our serial measurements reflect patterns of gastrin release.

It would have been interesting to study the relationship of the plasma gastrin level to acid secretion following a normal meal. This, however, was not possible since gastric acid could not be recovered and measured when there was food in the stomach. Rune (1966) tried to obviate this difficulty by measuring changes in the acid-base balance of the blood which resulted from acid secretion. He concluded that acid secretion after meals approximated to 'maximal' rates produced by infusion of histamine. Hence, it is possible that the rise in plasma 
gastrin concentration which was observed following a standard meal contributed, in part, to a powerful stimulus for acid secretion. However it is recognized that the plasma levels of gastrin, and the secretion of acid by the stomach, are the resultants of a number of processes tending to increase or decrease the levels of both at any one point in time. The changes in the levels of gastrin and gastric acid secretion cannot be interpreted by assuming that a simple relationship exists between them. The impression given by Fig. 3 is that Oxo raised the plasma gastrin level more than a standard meal. However, the difference just failed to reach statistical significance at the $5 \%$ level: whereas the meal raised the plasma gastrin by 100 to 200 $\mathrm{pg} / \mathrm{ml}$, Oxo raised it by 100 to $700 \mathrm{pg} / \mathrm{ml}$. Thus, in these experiments, the meal seemed to be a less variable stimulus than Oxo. The apparent differences between the responses to food and Oxo could probably be explained by their different physical and chemical composition, but it seems that Oxo was at least as effective as food in raising the plasma gastrin level. Gastric secretion could be easily measured in Oxo tests as they allowed the simultaneous measurement of gastrin levels and acid secretion.

Comparison of the results of Oxo tests and insulin tests showed that the mean plasma gastrin responses were surprisingly similar despite the very different stimuli used (Fig. 4). In individual patients, of course, the elevations of plasma gastrin were sometimes quite different in the two tests (Table III), but these pair differences were not significant. Thus, the two tests produced similar patterns of gastrin release, but insulin hypoglycaemia stimulated gastric acid secretion significantly more strongly than did Oxo. Insulin hypoglycaemia is known to act partly by direct stimulation of acid secretion and partly by releasing gastrin, whereas the mode of action of Oxo has not been defined. Nevertheless the Oxo test may be useful in assessing antral function by providing a measure of the ability of the antrum to release gastrin.
We gratefully acknowledge the financial assistance of the Wellcome Trust to develop the radioimmunoassay.

\section{References}

Anastasi, A., Erspamer, V., and Endean, R. (1967). Isolation and structure of caerulein, an active decapeptide from the skin of Hyla caerulea. Experientia (Basel), 23, 699-700.

Byrnes, D. J., Young, J. D., Chisholm, D. J., and Lazarus, L. (1970). Serum gastrin in patients with peptic ulceration. Brit. med.J., 2 , 626-629.

Clark, C. G., Curnow, V. J., Murray, J. G., Stephens, F. O., and Wyllie, J. H. (1964). Mode of action of histamine in causing gastric secretion in man. Gut, 5, 537-545.

Giles, G. R., and Clark, C. G. (1966). Gastric secretion stimulated by meat extract in man: a test of antral function. Scand. J. Gastroent., 1, 159-166.

Goodfriend, T. L., Levine, L., and Fasman, G. D. (1964). Antibodies to bradykinin and angiotensin: a use of carbodiimides in immunology. Science, 144, 1344-1346.

Hansky, J., and Cain, M. D. (1969). Radioimmunoassay of gastrin in human serum. Lancet, 2, 1388-1390.

Hassan, M. A., and Hobsley, M. (1970). Positioning of subject and of nasogastric tube during a gastric secretion study. Brit. med. J., $1,458-460$.

Herbert, V., Lau, K.-S., Gottlieb, C. W., and Bleicher, S. J. (1965). Coated charcoal immunoassay of insulin. J. clin. Endocr., 25, 1375-1384.

Hubel, K. A. (1966). Insulin-induced gastric acid secretion in young men. Gastroenterology, 50, 24-28.

Hunter, W. M., and Greenwood, F. C. (1962). Preparation of iodine131 labelled human growth hormone of high specific activity. Nature (Lond.), 194, 495-496.

Lewin, M. R., Hunziker, H. R., Stagg, B. H., and Wyllie, J. H. (1971). Radio-immunoassay of gastrin also measures degradation products. (Abstr). Brit. J. Surg., 58, 863.

McGuigan, J. E. (1968). Immunochemical studies with synthetic human gastrin. Gastroenterology, 54, 1005-1011.

McGuigan, J. E., and Trudeau, W. L. (1970). Studies with antibodies to gastrin: radioimmunoassay in human serum and physiological studies. Gastroenterology, 58, 139-150.

Mutt, V., and Jorpes, J. E. (1968). Structure of porcine cholecystokinin-pancreozymin. I. Cleavage with thrombin and with trypsin. Europ. J. Biochem., 6, 156-162.

Rune, S. J. (1966). Comparison of the rates of gastric acid secretion in man after ingestion of food and after maximal stimulation with histamine. Gut, 7, 344-350.

Temperley, J. M., and Stagg, B. H. (1971). Bioassay and radioimmunoassay of plasma gastrin in a case of Zollinger-Ellison syndrome. Scand. J. Gastroenterol., 6, 735-738.

Yalow, R. S., and Berson, S. A. (1970). Radioimmunoassay of gastrin. Gastroenterology, 58, 1-14.

Young, J. D., Lazarus, L., Chisholm, D. J., and Atkinson, F. F. V. (1969). Radioimmunoassay of pancreozymin cholecystokinin in human serum. J. nucl. Med., 10, 743-745. 